\title{
SYNTHESIS EVALUATION AND QUANTUM MECHANICAL CHARACTERIZATION OF CYCLOHEXYLAMINE CONTAINING DERIVATIVES OF METHYLXANTHINE
}

\author{
Maya Georgieva ${ }^{1}, J_{a v o r}$ Mitkov $^{2}$, Lily Peikova $^{3}$, Plamen Peikov $^{4}$, Alexander Zlatkov $^{5}$
}

\begin{abstract}
The synthesis of methylxanthine derivatives could provide a sound approach to developing new analogues with similar or novel pharmacological profiles. The synthesis of six new compounds: two derivatives of 8-substituted-1,3,7-trimethylxanthine and four derivatives of 1-propyl-3,7-dimethylxanthine containing a cyclohexyl fragment, are presented. The structures were confirmed by elemental analyses using Furrier Transform Infrared Spectroscopy (FTIR) and Nuclear Magnetic Resonance (NMR) spectral data. The chemical reactivity of the new molecules was assessed, based on computed values for their electrophilicity index, molecular hardness, and chemical potential. The structures were identified as hard molecules, relatively inert to electrophilic attack, whereas Compound10d was outlined as the most prominent for accepting electrons.
\end{abstract}

UDC Classification: 615.3 DOI: http://dx.doi.org/10.12955/cbup.v4.868

Keywords: 1 or 8- substituted methylxanthines, structural analysis, spectral analysis.

\section{Introduction}

Xanthine derivatives are of great interest in terms of their various pharmacological activities, which allow for their application in therapy, mainly as psycho- and respiratory-analeptics, bronchodilators, and diuretics (Persson, 1985). Some asymmetrically substituted xanthines are useful for treating central nervous system (CNS) diseases such as Alzheimer's type dementia (Boehringer Ingelheim KG, 1995). The investigation of the structure-activity relationships for methylxanthines is one approach establishing the role of substituents in the emergence of different types of biological activity (Persson, 1985). Another approach in developing new analogueswith similar or novel pharmacologicalprofiles is the synthesis of methylxanthinederivatives.

In a number of cases, the mechanism of action of methylxanthines and their derivatives is complex, and not fully established. The most probable hypothesis connected with this is that it occurs through either concurrent inhibition of the adenosine receptors or inhibition of the enzyme phosphodiesterase (Daly, Butts-Lamb \& Padgett, 1983; Daly,Padgett,\& Shamim, 1986; Ride, Farghaly,\& Ashour, 1977; Kakiuchi, Yamazaki, Teshima, Uenishi \& Miyamoto, 1975; Faulds,Chrisp, \& Buckley, 1991).

In the search for new compounds with improved bronchodilating properties and lowered toxicity, a quantitative structure-activity relationships (QSAR) study investigated a series of xanthine derivatives containing a cyclohexylamine fragment in the side chain, by applying the Optimized Approach Based on Structure Indices Set (OASIS; Mekenyan \&Bonchev, 1986). For this, two new compounds were outlined, and these yielded the beginning of a series of new methylxanthine derivatives, possessing a cyclohexylamine fragment in the side chain at N1 and C8 positions (Mekenyan, Stoyanova, Kamenska, Davkov, \& Peikov, 1993).

The aim of this study is to introduce a cyclohexylamine residue at $\mathrm{N} 1$ and $\mathrm{C} 8$ positions of the methylxanthines, and to evaluate the influence of these changes on certain physicochemical properties of the obtained structures. In order to achieve this, various derivatives of 1-substituted and 8substituted methylxanthines were prepared and the syntheses thereof were investigated.

\footnotetext{
${ }^{1}$ Maya Georgieva, Medical University, Faculty of Pharmacy, Department of Pharmaceutical Chemistry, 2 Dunav Street, 1000 Sofia, Bulgaria

${ }^{2}$ Javor Mitkov, Medical University, Faculty of Pharmacy, Department of Pharmaceutical Chemistry, 2 Dunav Street, 1000 Sofia, Bulgaria

${ }^{3}$ Lily Peikova, Medical University, Faculty of Pharmacy, Department of Pharmaceutical Chemistry, 2 Dunav Street, 1000

Sofia, Bulgaria

${ }^{4}$ Plamen Peikov, Medical University, Faculty of Pharmacy, Department of Pharmaceutical Chemistry, 2 Dunav Street, 1000 Sofia, Bulgaria

${ }^{5}$ Alexander Zlatkov, Medical University, Faculty of Pharmacy, Department of Pharmaceutical Chemistry, 2 Dunav Street, 1000 Sofia, Bulgaria
} 


\section{Experiment}

\section{Chemistry}

The necessary reagents were purchased from Fluktuierende Kaskade (FLUKA) and used without further purification. The corresponding melting points were measured in degrees Celsius $\left({ }^{\circ} \mathrm{C}\right)$ and then corrected (Büchi 535). The Furrier Transform Infrared Spectroscopy FTIR spectra in the region 400 $4000 \mathrm{~cm}^{-1}$ were recorded on a FT-IR Nicolet iS10 spectrophotometer in Nujol and the ${ }^{1} \mathrm{H}$ Nuclear Magnetic Resonance $\left({ }^{1} \mathrm{H}-\mathrm{NMR}\right)$ spectra were recorded at ambient temperature on a Bruker Avance DRX $250(250 \mathrm{MHz})$ spectrometer in dimethylsulfoxide $\left(\mathrm{DMSO}_{\mathrm{d}}\right)$. Chemical shifts were expressed as $\delta$ values in parts per million ( $\mathrm{ppm})$ against tetramethylsilane (TMS) as an internal reference; the coupling constants were expressed in Hertz (Hz). Analytical thin-layer chromatography (TLC) was used, performed on a DCAlufolien Kieselgel $60 \mathrm{~F}_{254}$ (Merck; $0.20 \mathrm{~mm}$ sheets) using a mobile phase with volumetric parts of $25 \%$ ammonium hydroxide: acetone: chloroform: ethanol (1:3:3:4), detected at the ultraviolet (UV) wavelength, $254 \mathrm{~nm}$. The yields were based on an analytically pure product and no effort was made to optimize the yields.

For synthesis of the necessary intermediates, the following is the list of the intermediates with the applied literary methods:

- Synthesis of 8-bromo-1,3,7-trimethylxanthine (Compound 2)

Gagausov, Peikov, Davkov, \& Sharankov (1987) proposed a method for synthesis of 8-bromomethylxanthines, which was applied to obtain Compound 2 with specifications of a yield of $79 \%$ and melting point (mp; ethanol) $206-208{ }^{\circ} \mathrm{C}$.

- Synthesis of 8-(2-hydroxyethylamino)-1,3,7-trimethylxanthine (Compound 4) and 8-(2chloroethylamino)-1,3,7-trimethylxanthine (Compound 5)

The Peikov,Zlatkov, Gagauzov, \& Kalinkova (1990) method was applied to obtain Compounds4 and 5.

- Synthesis of 1-(3-chlorodopropyl)-3,7-dimethylxanthine (Compound 8) and 1-(3-iodopropyl)3,7-dimethylxanthine (Compound 9)

The needed halogen derivative was synthesized from the corresponding sodium salt of the initial theobromine, according to the methodology presented in Peikov,Sidzhakova, \& Gagausov (1988).

For the synthesis of the new derivatives, the following lists the derivatives with the applied methods:

- Synthesis of 8-(N-methyl-N-cyclohexyl)-amino-1,3,7-trimethylxanthine (Compound 3)

In a Kjeldahl flask, $0.01 \mathrm{~mol}$ of 8-bromo-1,3,7-trimethylxanthine and $0.01 \mathrm{~mol}$ of $\mathrm{N}$ methylcyclohexylamine were mixed. This mixture was heated for $150 \mathrm{~min}$ at $100{ }^{\circ} \mathrm{C}$. After cooling to room temperature, a glassy mass was obtained and this was further processed with acetone while heating. After cooling, crystals from the corresponding hydrobromide salt were obtained, which were further recrystallized from ethanol/acetone. The specifications included a yield of 2.6g (69\%); IR $\left(\mathrm{cm}^{-1}\right): 1704(\nu \mathrm{C}=0), 1668(\nu \mathrm{C}=0), 1602,1545$, and $1525(\nu \mathrm{C}=\mathrm{C}$, $v \mathrm{C}=\mathrm{N}) ;{ }^{1} \mathrm{H}-\mathrm{NMR}\left(\mathrm{DMSO}_{\mathrm{d} 6}\right): 3.64\left(\mathrm{~s} ; 3 \mathrm{H} ; \mathrm{CH}_{3}-7^{\text {th }}\right.$ position$) ; 3.34\left(\mathrm{~s} ; 3 \mathrm{H} ; \mathrm{CH}_{3}-\mathrm{N}^{\text {th }}\right.$ position$)$; 3.17 (s; $3 \mathrm{H} ; \mathrm{CH}_{3}-3^{\text {rd }}$ position); and $1.11-1.76\left(\mathrm{~m} ; 11 \mathrm{H}\right.$; cyclohexyl) $;{ }^{13} \mathrm{C}$ NMR $\left(\mathrm{DMSO}_{\mathrm{d} 6}\right): \delta$ $25.6\left(\mathrm{C}-5^{\prime}\right), 26.7$ (C-3' and C-4'), 27.9, 29.6, $31.2\left(\mathrm{C}-2^{\prime}\right.$ and C-6'), 33.0, 35.0, $57.6\left(\mathrm{C}-1^{\prime}\right), 107.5$ (C-5), 146.4 (C-4), 151.25 (C-2), 155.2 (C-6), and 156.5 (C-8); $\mathrm{C}_{15} \mathrm{H}_{23} \mathrm{~N}_{5} \mathrm{O}_{2}$ (305.38); \% calculated: C 59.00, H 7.59, and N 22.93; and \% found: C 58.85, H 7.60, and N 22.85.

- Synthesis of 8-[2-(N-methyl-N-cyclohexyl)-aminoethyl]-1,3,7-trimethylxanthine (Compound 6)

In a Kjeldahl flask, $0.01 \mathrm{~mol}$ of 8-(2-chloroethylamino)-1,3,7-trimethylxanthine and $0.01 \mathrm{~mol}$ of $\mathrm{N}$-methylcyclohexylamine were mixed. This mixture was heated for $150 \mathrm{~min}$ at $100{ }^{\circ} \mathrm{C}$. After cooling to room temperature, a glassy mass was obtained and this was further processed with acetone under heating. After cooling of the latter, crystals from the corresponding hydrobromide salt were obtained and these were further recrystallized with ethanol/acetone. 
The specifications included a yield of 2.4g $(71 \%)$; IR $\left(\mathrm{cm}^{-1}\right): 1707(v \mathrm{C}=0), 1682(v \mathrm{C}=0)$, 1605,1555 , and $1525(v \mathrm{C}=\mathrm{C}, v \mathrm{C}=\mathrm{N}){ }^{1} \mathrm{H}-\mathrm{NMR}\left(\mathrm{DMSO}_{\mathrm{d} 6}\right): 3.64\left(\mathrm{~s}, 3 \mathrm{H}, \mathrm{CH}_{3}-7^{\text {th }}\right.$ position); $3.34\left(\mathrm{~s} ; 3 \mathrm{H} ; \mathrm{CH}_{3}-1^{\text {sth }}\right.$ position); $3.17\left(\mathrm{~s} ; 3 \mathrm{H} ; \mathrm{CH}_{3}-3^{\text {rd }}\right.$ position); and $1.11-1.76(\mathrm{~m} ; 11 \mathrm{H}$; cyclohexyl); ${ }^{13} \mathrm{C}$ NMR $\left(\mathrm{DMSO}_{\mathrm{d} 6}\right): \delta 26.0\left(\mathrm{C}-5^{\prime}\right), 25.0\left(\mathrm{C}-3^{\prime}\right.$ and C-4'), 28.0, 31.9, $31.3\left(\mathrm{C}-2^{\prime}\right.$ and C-6'), 37.4, 42.9, 54.8, 63.6 (C-1'), 108.3 (C-5), 147.2 (C-4), 151.2 (C-2), 154.8 (C-6), and 152.1 (C-8); $\mathrm{C}_{17} \mathrm{H}_{28} \mathrm{~N}_{6} \mathrm{O}_{2}$ (348.48); \% calculated: $\mathrm{C} 58.60, \mathrm{H} 8.10$, and $\mathrm{N} 24.12$; and \% found: C 58.45, H 8.02, and N 24.02.

- General procedure for the preparation of derivatives, 10a, 10b, 10c, and 10d, containing cyclohexylamine residue

An amount of 1-(3-iodopropyl)-3,7-dimethylxanthine $(0.01 \mathrm{~mol})$ and $0.01 \mathrm{~mol}$ of the corresponding amine were mixed in a suitable round-bottom flask. The reaction mixture was heated at $100^{\circ} \mathrm{C}$ while stirring for 30 to 60 minutes, depending on the used amine. After cooling to room temperature, a glassy mass was obtained that was processed with acetone under heating. After cooling, crystals from the corresponding hydrogeniodine salt were obtained and these were further recrystallized with ethanol/acetone. The obtained structures were further elucidated with FTIR and ${ }^{1} \mathrm{H}-\mathrm{NMR}$ analysis, and their purity was confirmed for their corresponding melting points and TLC-characteristics.

- Synthesis of 1-[3-(cyclohexylamino)-propyl)-3,7-dimethylxanthine (Compound 10a)

The specifications included a yield of 3.7g $(60 \%)$; IR $\left(\mathrm{cm}^{-1}\right): 1703(\nu \mathrm{C}=0), 1656(\nu \mathrm{C}=0)$, 1603, 1547, and1545 ( $v \mathrm{C}=\mathrm{C}, v \mathrm{C}=\mathrm{N}) ;{ }^{1} \mathrm{H}-\mathrm{NMR}\left(\mathrm{DMSO}_{\mathrm{d} 6}\right): 12.47(\mathrm{~s} ; 1 \mathrm{H} ; \mathrm{NH}) ; 7.61(\mathrm{~s} ; 1 \mathrm{H}$; $8^{\text {th }}$ position: xanth); $3.83\left(\mathrm{~d} ; 2 \mathrm{H} ; \mathrm{N} 1-\mathrm{CH}_{2} ; \mathrm{J}=2.67 \mathrm{~Hz}\right) ; 3.74\left(\mathrm{~s} ; 3 \mathrm{H} ; \mathrm{CH}_{3}-7^{\text {th }}\right.$ position $) ; 3.32$ (s; $3 \mathrm{H} ; \mathrm{CH}_{3}-3^{\text {rd }}$ position); $2.68\left(\mathrm{~d} ; 2 \mathrm{H} ; \mathrm{N}-\mathrm{CH}_{2} ; \mathrm{J}=2.67 \mathrm{~Hz}\right) ; 2.47$ (q; $1 \mathrm{H} ; 1^{\text {sth }}$ position: cyclohexyl$\mathrm{N}) ; 1.87\left(\mathrm{~m} ; 2 \mathrm{H} ; \mathrm{CH}_{2} \mathrm{CH}_{2} \mathrm{CH}_{2}\right) ; 1.48\left(\mathrm{~m} ; 4 \mathrm{H} ; 2^{\text {nd }}\right.$ and $6^{\text {th }}$ position: cyclohexyl); $1.47\left(\mathrm{~m} ; 4 \mathrm{H} ; 3^{\text {rd }}\right.$ and $5^{\text {th }}$ position: cyclohexyl); and $1.35\left(\mathrm{~d} ; 2 \mathrm{H} ; 4^{\text {th }}\right.$ position: cyclohexyl); ${ }^{13} \mathrm{C}$ NMR (DMSO $\left.{ }_{\mathrm{d} 6}\right): \delta$ 25.6 (C-5'), 26.1 (C-3' and C-4'), 28.3, 28.6, 31.7 (C-2' and C-6'), 31.5, 42.5, 45.1, $59.5\left(\mathrm{C}-1^{\prime}\right)$, 107.8 (C-5), 142.5 (C-4), 143.8 (C-8), 155.3 (C-2), and 156.7 (C-6); $\mathrm{C}_{16} \mathrm{H}_{25} \mathrm{~N}_{5} \mathrm{O}_{2}$ (319.41); \% calculated: C 60.17, H 7.89, and N 21.93; and\% found: C 59.95, H 7.77, and N 21.86.

- Synthesis of 1-[3-(N-methylcyclohexylamino)-propyl)-3,7-dimethylxanthine (Compound 10b)

The specifications included a yield of 2.5g (54\%); IR (Nujol): $1707(v \mathrm{C}=0), 1663(\nu \mathrm{C}=0)$, 1603, 1573, and $1520(v \mathrm{C}=\mathrm{C}, v \mathrm{C}=\mathrm{N}){ }^{1} \mathrm{H}-\mathrm{NMR}\left(\mathrm{DMSO}_{\mathrm{d}}\right): 7.61\left(\mathrm{~s} ; 1 \mathrm{H} ; 8^{\text {th }}\right.$ position: xanth); $3.83\left(\mathrm{~d} ; 2 \mathrm{H} ; \mathrm{N} 1-\mathrm{CH}_{2} ; \mathrm{J}=2.67 \mathrm{~Hz}\right) ; 3.74\left(\mathrm{~s} ; 3 \mathrm{H} ; \mathrm{CH}_{3}-7^{\text {th }}\right.$ position $) ; 3.32\left(\mathrm{~s} ; 3 \mathrm{H} ; \mathrm{CH}_{3}-3^{\text {rd }}\right.$ position); $2.72\left(\mathrm{~d} ; 2 \mathrm{H} ; \mathrm{N}-\mathrm{CH}_{2} ; \mathrm{J}=2.67 \mathrm{~Hz}\right) ; 2.46\left(\mathrm{q} ; 1 \mathrm{H} ; 1^{\text {sth }}\right.$ position: cyclohexyl-N); $2.24(\mathrm{~s}$; $\left.3 \mathrm{H} ; \mathrm{N}-\mathrm{CH}_{3}\right) ; 1.93\left(\mathrm{~m} ; 2 \mathrm{H} ; \mathrm{CH}_{2} \mathrm{CH}_{2} \mathrm{CH}_{2}\right) ; 1.58\left(\mathrm{~m} ; 4 \mathrm{H} ; 2^{\text {nd }}\right.$ and $6^{\text {th }}$ position: cyclohexyl); 1.48 $\left(\mathrm{m} ; 4 \mathrm{H} ; 3^{\text {rd }}\right.$ and $5^{\text {th }}$ position: cyclohexyl); and $1.36\left(\mathrm{~d} ; 2 \mathrm{H} ; 4^{\text {th }}\right.$ position: cyclohexyl $) ;{ }^{13} \mathrm{C}$ NMR $\left(\mathrm{DMSO}_{\mathrm{d} 6}\right): \delta 25.9\left(\mathrm{C}-5^{\prime}\right), 24.9\left(\mathrm{C}-3^{\prime}\right.$ and C-4'), 26.3, 30.2, $31.4\left(\mathrm{C}-2^{\prime}\right.$ and C-6'), 31.5, 42.5, 43.0, 52.8, $65.8\left(\mathrm{C}-1^{\prime}\right), 107.9$ (C-5), 142.5 (C-4), 147.3 (C-8), 155.2 (C-2), and156.5 (C6); $\mathrm{C}_{17} \mathrm{H}_{27} \mathrm{~N}_{5} \mathrm{O}_{2}$ (333.43); \% calculated: $\mathrm{C} 61.24, \mathrm{H} 8.16$, and $\mathrm{N} 21.00$; and $\%$ found: $\mathrm{C} 60.96$, $\mathrm{H} 8.00$, and $\mathrm{N} 20.87$.

- Synthesis of 1-[3-(N-ethylcyclohexylamino)-propyl)-3,7-dimethylxanthine (Compound 10c)

The specifications included a yield of $2.3 \mathrm{~g}(49 \%)$; IR $\left(\mathrm{cm}^{-1}\right): 1703(\nu \mathrm{C}=0), 1654(\nu \mathrm{C}=0)$, 1600, 1542, and $1507(v \mathrm{C}=\mathrm{C}, v \mathrm{C}=\mathrm{N}) ;{ }^{1} \mathrm{H}-\mathrm{NMR}\left(\mathrm{DMSO}_{\mathrm{d} 6}\right): 7.61\left(\mathrm{~s} ; 1 \mathrm{H} ; 8^{\text {th }}\right.$ position: xanth); $3.83\left(\mathrm{~d} ; 2 \mathrm{H} ; \mathrm{N} 1-\mathrm{CH}_{2} ; \mathrm{J}=2.67 \mathrm{~Hz}\right) ; 3.74\left(\mathrm{~s} ; 3 \mathrm{H} ; \mathrm{CH}_{3}-7^{\text {th }}\right.$ position $) ; 3.32\left(\mathrm{~s} ; 3 \mathrm{H} ; \mathrm{CH}_{3}-3^{\text {rd }}\right.$ position); $2.77\left(\mathrm{~d} ; 2 \mathrm{H} ; \mathrm{N}-\mathrm{CH}_{2} ; \mathrm{J}=2.67 \mathrm{~Hz}\right) ; 2.72\left(\mathrm{~m} ; 2 \mathrm{H} ; \mathrm{N}-\mathrm{CH}_{2} \mathrm{CH}_{3}\right) ; 2.47\left(\mathrm{q} ; 1 \mathrm{H} ; 1^{\text {sth }}\right.$ position: cyclohexyl-N); $1.93\left(\mathrm{~m} ; 2 \mathrm{H} ; \mathrm{CH}_{2} \mathrm{CH}_{2} \mathrm{CH}_{2}\right) ; 1.64\left(\mathrm{~m} ; 4 \mathrm{H} ; 2^{\text {nd }}\right.$ and $6^{\text {th }}$ position: cyclohexyl); $1.49\left(\mathrm{~m} ; 4 \mathrm{H} ; 3^{\text {rd }}\right.$ and $5^{\text {th }}$ position: cyclohexyl); and $1.35\left(\mathrm{~d} ; 2 \mathrm{H} ; 4^{\text {th }}\right.$ position: cyclohexyl); ${ }^{13} \mathrm{C}$ NMR $\left(\mathrm{DMSO}_{\mathrm{d} 6}\right): \delta$ 11.5, $26.0\left(\mathrm{C}-5^{\prime}\right), 25.5\left(\mathrm{C}-3^{\prime}\right.$ and C-4'), 28.3, $30.1\left(\mathrm{C}-2^{\prime}\right.$ and C-6'), 30.7, 31.5, 42.9, 46.3, 52.9, 67.4 (C-1'), 107.9 (C-5), 142.5 (C-4), 143.7 (C-8), 155.3 (C2), and 156.7 (C-6); $\mathrm{C}_{18} \mathrm{H}_{29} \mathrm{~N}_{5} \mathrm{O}_{2}$ (347.46); \% calculated: $\mathrm{C} 62.22, \mathrm{H} 8.41$, and $\mathrm{N} 20.16$; and \% found: C 62.05, $\mathrm{H} 8.33$, and $\mathrm{N} 20.08$. 
- Synthesis of 1-[3-(N,N-dicyclohexylamino)-propyl)-3,7-dimethylxanthine (Compound 10d)

The specifications included a yield of $2.2 \mathrm{~g}(42 \%)$; IR $\left(\mathrm{cm}^{-1}\right): 1699(\nu \mathrm{C}=0), 1652(v \mathrm{C}=0)$, 1600, 1571, and $1550(v \mathrm{C}=\mathrm{C}, v \mathrm{C}=\mathrm{N}){ }^{1} \mathrm{H}-\mathrm{NMR}\left(\mathrm{DMSO}_{\mathrm{d} 6}\right): 7.60\left(\mathrm{~s} ; 1 \mathrm{H} ; 8^{\text {th }}\right.$ position: xanth); $3.84\left(\mathrm{~d} ; 2 \mathrm{H} ; \mathrm{N} 1-\mathrm{CH}_{2} ; \mathrm{J}=2.67 \mathrm{~Hz}\right) ; 3.73\left(\mathrm{~s} ; 3 \mathrm{H} ; \mathrm{CH}_{3}-7^{\text {th }}\right.$ position $) ; 3.32\left(\mathrm{~s} ; 3 \mathrm{H} ; \mathrm{CH}_{3}-3^{\text {rd }}\right.$ position); $2.90\left(\mathrm{~d} ; 2 \mathrm{H} ; \mathrm{N}-\mathrm{CH}_{2} ; \mathrm{J}=2.67 \mathrm{~Hz}\right) ; 2.48\left(\mathrm{q} ; 2 \mathrm{x} 1 \mathrm{H} ; 1^{\text {sth }}\right.$ position-cyclohexyl-N); 1.94 (m; $\left.2 \mathrm{H} ; \mathrm{CH}_{2} \mathrm{CH}_{2} \mathrm{CH}_{2}\right) ; 1.65$ ( $\mathrm{m} ; 2 \mathrm{x} 4 \mathrm{H} ; 2^{\text {nd }}$ and $6^{\text {th }}$ position: cyclohexyl); $1.48\left(\mathrm{~m} ; 2 \mathrm{x} 4 \mathrm{H} ; 3^{\text {rd }}\right.$ and $5^{\text {th }}$ position: cyclohexyl); $1.35\left(\mathrm{~d} ; 2 \times 2 \mathrm{H} ; 5^{\text {th }}\right.$ position: cyclohexyl); and $0.99(\mathrm{~m} ; 3 \mathrm{H} ; \mathrm{N}-$ $\mathrm{CH}_{2} \mathrm{CH}_{3}$ ); ${ }^{13} \mathrm{C}$ NMR (DMSO ${ }_{\mathrm{d} 6}$ ): $\delta 26.0$ (C-5' and C-5"), 25.1 (C-3', C-3", C-4', and C-4"), 28.3, 31.2, 32.4 (C-2', C-2", C-6', and C-6"), 43.1, 49.5, 65.1 (C-1' and C-1"), 107.8 (C-5), 142.5 (C4), 143.8 (C-8), 155.2 (C-2), and 156.7 (C-6); $\mathrm{C}_{22} \mathrm{H}_{35} \mathrm{~N}_{5} \mathrm{O}_{2}$ (401.55); \% calculated: $\mathrm{C} 68.81, \mathrm{H}$ 8.79, and N 17.44; and \% found: C 68.85, H 8.68, and N 17.05.

\section{Results and Discussions}

The targeted 8-substituted derivatives of 1,3,7-trimethylxanthine, containing a cyclohexylamino residue (Compounds 3 and 6) were obtained from 8-bromocaffeine using the literary method in Gagausov and associates (1987), and according to the scheme given below (Figure 1):

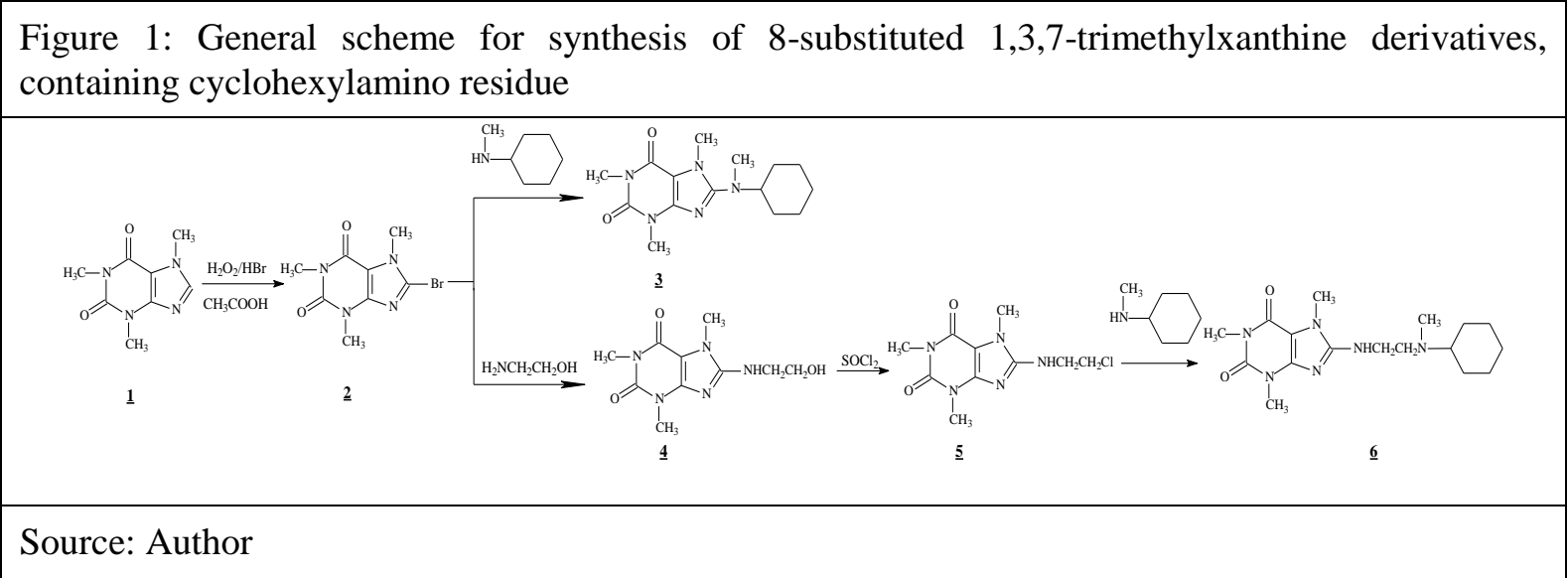

The amination of 8-bromocaffeine ((2), Figure 1) with the corresponding amino alcohol was carried out at temperature of $130^{\circ} \mathrm{C}$, in the absence of solvent, with the reaction time established as 15-25 min. The running of the process was followed by TLC control until exhaustion of the reagents. This method ensured high yields of the obtained 8-(hydroxyethyl)-aminocaffeine ((4), Figure 1). The isolated caffeine derivative was processed with thionyl chloride to obtain the corresponding halogen derivative ((5), Figure 1), which further interacted with the chosen cyclohexylamine to produce the target derivative ((6), Figure 1). The reaction ended with close to quantitative yields.

The next synthetic scheme (Figure 2) represents the synthesis of the cyclohexylamino containing derivatives of 1-propyl-3,7-dimethylxanthine,10a, 10b, 10c and10d, as follows:

Figure 2: General scheme for synthesis of derivatives of 1-propyl-3,7-dimethylxanthine, containing a cyclohexylamino residue

Source: Author


The chemical structures and certain physicochemical properties of the studied N1 or C8 substituted derivatives are presented in Table 1.

Table 1: Chemical structures and certain physicochemical properties of the obtained N1 or C8 substituted derivatives

\begin{tabular}{|l|l|l|r|r|r|}
\hline & $\begin{array}{c}\text { Compound } \\
\text { ID }\end{array}$ & \multicolumn{1}{|c|}{$\mathbf{R}$} & $\begin{array}{c}\text { Molecular } \\
\text { weight } \\
(\mathbf{g} / \mathbf{m o l})\end{array}$ & $\begin{array}{c}\text { Melting } \\
\text { point } \\
\left({ }^{\circ} \mathbf{C}\right)\end{array}$ & $\begin{array}{c}\text { Yield } \\
(\%)\end{array}$ \\
\cline { 2 - 5 } & $\mathbf{3}$ & $\mathrm{CH}_{3}$ & 305.38 & $132-133$ & 69 \\
\hline $\mathbf{6}$ & $\mathrm{CH}_{3}$ & 348.48 & $161-162$ & 71 \\
\hline $\mathbf{1 0 a}$ & $\mathrm{H}$ & 319.41 & $214-217$ & 60 \\
\hline $\mathbf{1 0 b}$ & $\mathrm{CH}_{3}$ & 333.43 & $190-193$ & 54 \\
\hline $\mathbf{1 0 c}$ & $\mathrm{C}_{2} \mathrm{H}_{5}$ & 347.46 & $188-189$ & 49 \\
\hline $\mathbf{1 0 d}$ & $\mathrm{cyclohexyl}$ & 401.55 & $180-183$ & 42 \\
\hline
\end{tabular}

As the melting point of theobromine is $357^{\circ} \mathrm{C}$, it became apparent that this temperature declined when the substituent was at position N1, whereas the presence of the alkyl group in the N-atom of the side chain led to a larger decrease in the melting points of the corresponding compounds, $10 \mathrm{~b}$ and $10 \mathrm{c}$. The length of this alkyl residue had no significant influence on the value of the decrease.

Considering the melting point of caffeine is $238{ }^{\circ} \mathrm{C}$, similar observations to those stated above can be made for caffeine. Since there was an apparent decline in the temperatures for derivatives, Compounds 3 and 6 in the presence of a longer alkyl side chain at C8, led to a lower decrease in the melting point. These effects may be explained by the dependence of the corresponding polarity of the " $\mathrm{R}$ " substituent (Avadanei et.al., 2011).

The obtained compounds were characterized by microanalyses using FTIR and NMR spectrometry, and the results were consistent with those for the examined structures 3,6, 10a-d.

The IR spectra of the obtained 1-propyl-3,7-dimethylxantheine and 8-substituted 1,3,7trimethylxanthine derivatives, which contained a cyclohexyl residue in the region $4000 \mathrm{~cm}^{-1}$ to $400 \mathrm{~cm}^{-}$ ${ }^{1}$, exhibited several characteristic bands. The absorption bands $3555-3267 \mathrm{~cm}^{-1}$ are ascribable to symmetrical and anti-symmetrical stretching vibrations of $\mathrm{NH}$ groups, presented in the spectra of the studied derivatives containing a cyclohexylamino residue. Complex and broad bands, in the region $3100-2810 \mathrm{~cm}^{-1}$, were observed in the spectra of the studied compounds. These bands were assigned to the out-of-plane and in-plane asymmetric and symmetric $\mathrm{CH}_{2}$ and $\mathrm{CH}_{3}$ stretching vibrations, respectively. These assignments appeared due to the incorporated cyclohexyl substituents and are supported in literary data (Silverstein, 1981). The two strong bands at $1652-1703 \mathrm{~cm}^{-1}$ were ascribed to stretching vibrations of two carbonyl groups in the xanthine ring. The band of bending vibration of $\mathrm{NH}$ - group (amide II) was in the $1603-1549 \mathrm{~cm}^{-1}$ region where stretching vibrations of $\mathrm{C}^{4}=\mathrm{C}^{5}$ and $\mathrm{C}^{8}=\mathrm{N}^{9}$ bands from the xanthine ring appear, though appearing stronger than these latter bands. The absorption bands at about $1377 \mathrm{~cm}^{-1}$ were ascribed to skeletal vibrations of xanthine ring. Our investigations showed that the stretching vibrations of $\mathrm{C}=\mathrm{N}$ and $\mathrm{C}-\mathrm{N}$ bonds had the greatest contribution to these vibrations. Three bands of absorption were observed in this region of the spectra of the studied compounds, and may be due to the solid-state effects (Czuchajowski \& Eckstein, 1967). The ${ }^{1} \mathrm{H}$ and ${ }^{13} \mathrm{C}-\mathrm{NMR}$ data determined the proposed structures of the investigated compounds.

In an attempt to establish dependencies between the molecular geometry, i.e., the calculated electrooptical parameters and the compound's structure, the synthesized compounds were subjected to theoretical analysis. The full optimization of the molecular geometry of the studied structures was performed with the program VEGAZZ ver. 3.0.1.22 (http://nova.colombo58.unimi.it/) using PM7 semi empirical method (Stewart, 2013).

The obtained computed values for certain molecular parameters are shown on Table 2. 
Table 2: Computed molecular parameters for the new compounds

\begin{tabular}{|c|c|c|c|c|c|c|}
\hline $\begin{array}{ll} & \text { Compound } \\
\text { Properties } & \end{array}$ & 3 & 6 & $10 \mathbf{a}$ & $10 b$ & 10c & 10d \\
\hline Total energy (E) (kcal/mol) & -90203 & -102472 & -93808 & -97386 & -100979 & -114708 \\
\hline Dipole moment (p) (D) & 4.196 & 4.401 & 4.009 & 3.568 & 2.976 & 3.141 \\
\hline HOMO (eV) & -8.775 & -8.707 & -8.950 & -8.658 & -8.810 & -8.586 \\
\hline LUMO (eV) & -0.253 & -0.260 & -0.341 & -0.377 & -0.362 & -0.323 \\
\hline Surface area $\left(\AA^{2}\right)$ & 521.27 & 601.18 & 581.07 & 554.93 & 584.45 & 661.47 \\
\hline Volume $\left(\AA^{\mathbf{3}}\right)$ & 891.37 & 1032.38 & 974.96 & 975.90 & 1026.09 & 1171.28 \\
\hline \begin{tabular}{|lll} 
Hidration energy & (HE) \\
(kcal/mol)
\end{tabular} & 0.54 & -1.31 & -2.02 & -0.57 & -0.25 & -0.08 \\
\hline $\log P$ & 1.40 & 1.02 & 0.19 & 0.56 & 0.90 & 2.14 \\
\hline Refractivity $(\mathbf{R})\left(\AA^{3}\right)$ & 83.96 & 96.69 & 88.61 & 93.91 & 98.65 & 114.92 \\
\hline Polarizability $(\alpha)\left(\AA^{3}\right)$ & 32.29 & 37.32 & 34.13 & 35.97 & 37.80 & 44.37 \\
\hline Mass (amu) & 305.38 & 348.45 & 319.41 & 333.43 & 347.46 & 401.55 \\
\hline
\end{tabular}

Source: Author

A graphical representation of the deviation in the highest occupied molecular orbital (HOMO) values $(\mathrm{eV})$, computed by HyperChem 8.0.6, is given in Figure 3. The presence of a secondary $\mathrm{N}$-atom in the structure of Compound 10a yielded the lowest HOMO value, and this indicated it was the most stable compound. However, the highest HOMO energy values were observed with substitution in the N-atom with alkyl-and cycloalkyl substituents, whereas the highest HOMO value was observed with Compound10d, containing dicyclohexylamine residue.

Figure 3: Computed value of highest occupied molecular orbital HOMO $(\mathrm{eV})$ for the studied compounds

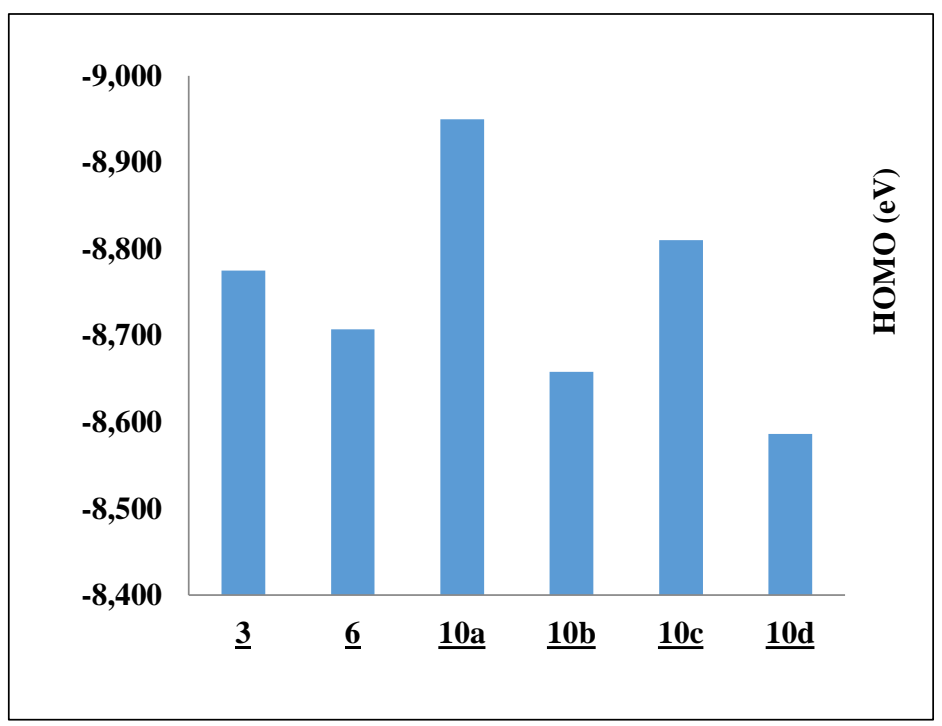

3: 8-(N-methyl-N-cyclohexyl)-amino-1,3,7-trimethylxanthine

6: 8-[2-(N-methyl-N-cyclohexyl)-aminoethyl]-1,3,7-trimethylxanthine

10a: 1-[3-(cyclohexylamino)-propyl)-3,7-dimethylxanthine

10b: 1-[3-(N-methylcyclohexylamino)-propyl)-3,7-dimethylxanthine

10c: 1-[3-(N-ethylcyclohexylamino)-propyl)-3,7-dimethylxanthine

10d: 1-[3-(N,N-dicyclohexylamino)-propyl)-3,7-dimethylxanthine

Source: Author 
Certain dependencies of the calculated and presented parameters from the chemical structure and electronic characteristics of the compounds were identified (Table 2). A linear dependency of the computed total energy from the polarizability was established, as presented on Figure 4. It was observed, that the basicity of the $\mathrm{N}$-atom in the side chain of the substituent, at Position 8 in the 1,3,7thrimethylxantine core, had a strong influence on this dependency, while its strong increase or decrease led to deflections from the linearity.

Figure 4: Computed value of total energy $(\mathrm{kcal} / \mathrm{mol})$ vs molecular polarizability for the studied compounds

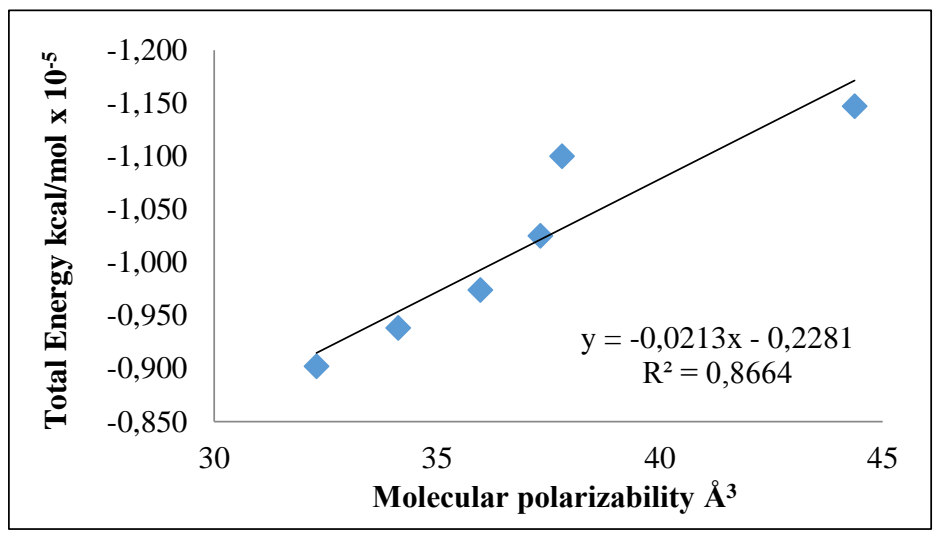

Source: Author

The proposed model was sound, considering the value of the $\mathrm{R}^{2}$ was close to 1 .

Some molecular parameters for the newly synthesized derivatives, like electrophilicity index, chemical potential and molecular hardness, were computed using data in Table 2 to assess their chemical reactivity. The obtained values are presented in Table 3 .

Table 3: Chemical potential, hardness, and electrophilicity index of the compounds estimated using data from Table 2

\begin{tabular}{|c|c|c|c|c|c|c|c|}
\hline Compound & HOMO & LUMO & $\Delta_{\text {HOMO-LuMO }}$ & $\boldsymbol{\mu}$ & $\boldsymbol{\eta}$ & $\boldsymbol{s}$ & $\boldsymbol{\omega}$ \\
\hline $\mathbf{3}$ & -8.775 & -0.253 & 8.522 & -4.51 & 8.52 & 0.50 & 1.20 \\
\hline $\mathbf{6}$ & -8.707 & -0.260 & 8.447 & -4.48 & 8.45 & 0.50 & 1.19 \\
\hline $\mathbf{1 0 a}$ & -8.950 & -0.341 & 8.609 & -4.65 & 8.61 & 0.50 & 1.25 \\
\hline $\mathbf{1 0 b}$ & -8.658 & -0.377 & 8.281 & -4.52 & 8.28 & 0.50 & 1.23 \\
\hline $\mathbf{1 0 c}$ & -8.810 & -0.362 & 8.448 & -4.59 & 8.45 & 0.50 & 1.24 \\
\hline $\mathbf{1 0 d}$ & -8.586 & -0.323 & 8.263 & -4.45 & 8.26 & 0.50 & 1.20 \\
\hline
\end{tabular}

HOMO: highest occupied molecular orbital LUMO: lowest unoccupied molecular orbital

Source: Authors

The electrophilicity index $(\omega)$ is a useful descriptor, which represents the tendency of a molecule to accept electrons and is defined by the following equation:

$$
\omega=\frac{\mu^{2}}{2 \eta}
$$

where $\omega$ is the electrophilicity index; $\mu$ is the chemical potential and $\eta$ is the hardness. 
High values of $\mu$ and $\omega$ establish the molecule as a strong electrophile, while low values of $\mu$ and $\omega$ identify it as a strong nucleophile (Srivastava et.al., 2012).

The calculated $\omega$ values for the elucidated compounds were comparable, indicating all molecules had equal capacity to absorb electrons.

Another informational descriptor for the chemical reactivity of a molecule is the chemical potential $(\mu)$. In the present work, $\mu$ was calculated, using the formula:

$$
\mu=\frac{H O M O+L U M O}{2}
$$

where $\mu$ is the chemical potential, HOMO stands for the highest occupied molecular orbital and LUMO stands for the lowest unoccupied molecular orbital.

The obtained values followed the tendency expressed for the electrophilicity index and confirmed the comparability in the potency of the newly synthesized 1-propyl-3,7-dimethylxanthines or 8-substituted 1,3,7-trimethylxanthines containing a cyclohexyl residue to accept electrons.

The hardness $(\eta)$ is a direct measure of the electrophilic stability of the molecule and is defined by the equation (3):

$$
\eta=\frac{L U M O-H O M O}{2}
$$

This parameter indicates the resistance of the molecule to charge transfer. In general, a molecule with a high value of $\eta$, will show an inert characteristic of electrophilic attack (Ayres \& Parr, 2000). The descriptor that is opposite in meaning, the softness $(s)$, is described by the equation (4):

$$
s=\frac{1}{2 \eta}
$$

which measures the tendency of a charge transfer. Therefore, a molecule with a low value of $s$ is expected to be stable under electrophilic attack. Thus, the computed $\eta$ and $s$ values for the discussed structures determine the ability of a compound to attract electrons (Srivastava et.al., 2015). The obtained results for the ability of the discussed structures to attract electrons are in order 10a $>3>6=$ $10 \mathrm{c}>10 \mathrm{~b}>10 \mathrm{~d}$, showing Compound $10 \mathrm{~d}$ as most prominent.

The HOMO/LUMO gap is a measurement of the redox potential and has been used to determine the bioactivity of the intramolecular charge transfer (Arivazharan \& Senthil Kumar, 2012). According to this approach, the lower negative HOMO energies and the negative values of the LUMO energies correspond to compounds with reductive properties. A large value of the gap refers to large excitation energies and is characteristic of "hard" molecules. This study's results for the hardness $(\eta)$ indicated the studied compounds can be accepted as hard molecules.

\section{Conclusion}

Six new derivatives of 1-propyl-3,7-dimethylxanthine and 8-substituted 1,3,7-trimethylxanthine containing a cyclohexylamino residue, were synthesized.The obtained molecules were characterized by microanalyses, using FTIR and NMR spectrometry, and the results were consistent with the assigned structures. The chemical reactivity of the obtained compounds was assessed, using molecular parameters, such as the electrophilicity index, chemical potential, and molecular hardness. The results indicate that all molecules had equal capacity to absorb electrons, while Compound 10d (1-[3-(N, Ndicyclohexylamino)-propyl)-3,7-dimethylxanthine) was the most prominent in accepting electrons. All structures may be considered as hard molecules, relatively inert to electrophilic attack.

\section{References}

Arivazharan M., Senthil Kumar J. (2012). Vibrational assignment, HOMO - LUMO, first-hyperpolarizability and Muliken's charge analysis of 2,7-dinitrofluorene. Indian Journal of Pure \& Applied Physics, 50, 363-373

Avadanei M., Dulcescu M., Profire L., Barboiu V., Dorohoi D.-O. (2011). Spectral and quantum-mechanical characterization of 7-[2-hydroxy-3(-4-acetyl-amino)-phenoxy-propyl]-1,3 dimethyl xantine derivatives. Digest Journal of Nanomaterials and Biostructures, 6(3), 1149-1160 
Ayres P.W., Parr R.G. (2000). Variational Principles for Describing Chemical Reactions: The Fukui Function and Chemical Hardness Revisited. J. Am. Chem. Soc., 122, 2010-2018.]

Boehringer Ingelheim KG (1995). DE 4325254 :03.

Czuchajowski L., Eckstein M. (1967). Infra-red absorption spectra of some 7-mono and 7,8-disubstituted theophylline and 1substituted theobromine derivatives. Roczh. Chem., 41, 909-915.

Daly J. W.,Butts-Lamb P.,Padgett W. (1983). Subclasses of adenosine receptors in the central nervous system: Interaction with caffeine and related methylxanthines. Cell. Moll. Neurobiol., 3, 69-80

Daly J. W.,Padgett W. L.,Shamim M. T. (1986). Analogs of 1,3-dipropyl-8-phenylxanthine: enhancement of selectivity at A1-adenosine receptors by aryl substituents. J. Med. Chem., 29, 1520-1524

Faulds D., Chrisp P., Buckley M. M. (1991). Adenosine. An evaluation of its use in cardiac diagnostic procedures, and in the treatment of paroxysmal supraventricular tachycardia. Drugs, 41(4), 606-608

Gagausov J., Peikov Pl., Davkov D., Sharankov K. (1987). Synthesis of 8-brom-methylxanthines. Farmacia, 37(6), 8-10

Kakiuchi S.,Yamazaki R.,Teshima Y.,Uenishi K.,Miyamoto E. (1975). Multiple cyclic nucleotide phosphodiesterase activities from rat tissues and occurrence of a calcium-plus-magnesium-ion-dependent phosphodiesterase and its protein activator. Biochem. J., 146(1), 109-120

Mekenyan, O., Bonchev, D. (1986). OASIS method for predicting bio-logical activity of chemical compounds. Acta Pharm. Jugosl. 36, 225-237.

Mekenyan, O., Stoyanova G., Kamenska V., Davkov D., Peikov P. (1993). Bronchospasmolitic activity and toxicity modeling of theophylline derivatives by microcomputer based method. Arzneim. Forsch. 43, 1341-1350

Peikov Pl., Zlatkov Al., Gagauzov J., Kalinkova G. (1990). Preparation of some 8-(bromoalkylamino)-caffeines and infra red spectra. Farmacia,40(3), 1-6

Peikov P., Sidzhakova D., Gagausov J. (1988). Laboratory technology of synthesis of 1-(3-iodoropropyl)-3,7dimethylxanthine. Farmacia, 38, 1-4

Persson, C.G.A. (1985). Antiasthma xantines and adenosine, Copenhagen, 25-36

Ride S. M., Farghaly A.M., Ashour F.A.(1977). Synthesis and pharmacological testing on some theophylline esters. Pharmazie, 32(11), 672-676

Silverstein M., Clayton G., Basseler, Morill C. (1981). Spectrometric Identification ofOrganic Compounds, Wiley\& Sons: New York.

Srivastava A., Mishra R., Kumar S., Dev K., Tandon P., Maurya R. (2015). Molecular structure, spectral investigation (1H NMR, 13C NMR, UV-Visible, FT-IR, FT-Raman), NBO, intramolecular hydrogen bonding, chemical reactivity and first hyperpolarizability analysis of Formononetin [7-hydroxy-3(4-methoxyphenyl)chromone]: A quantum chemical study. Journal of Molecular Structure, 1084, 55-73

Stewart J.J.P. (2013). Optimization of parameters for semiempirical methods VI: more modifications to the NDDO approximations and re-optimization of parameters. J Mol Model., 19(1), 1-32.

Srivastava A., Rawat P., Tandon P., Singh R.N. (2012). A computational study on conformational geometries, chemical reactivity and inhibitor property of an alkaloid bicuculline with $\gamma$-aminobutyric acid (GABA) by DFT. Comput. Theor. Chem. 993, 80-89 